\title{
СТАТУС ЖЕНЩИНЫ В КИМАКСКОМ ОБЩЕСТВЕ В ТРУДАХ Ф.Х. АРСЛАНОВОЙ
}

\author{
(C) 2019 г. Б.М. Хасенова
}

\begin{abstract}
В научном творчестве Ф.Х. Арслановой значительное место занимают гендерные исследования. Автором высказано мнение об особом социальном статусе женщин, чей погребальный инвентарь содержал предметы торевтики (эти погребения также отличались специфическим размещением в составе семейной группы и в пространстве могильника). Несмотря на то, что исследовательницей были получены важнейшие сведения по погребальному обряду представителей кимакской знати, важно отметить, что в научном плане ее интересовал статус именно женщины. Ф.Х. Арсланова стала новатором гендерных исследований в археологии Казахстана.

Ключевые слова: археология, Ф.Х. Арсланова, Восточный Казахстан, Прииртышье, эпоха средневековья, Кимакский каганат, история археологии, общество, гендерные исследования, женщина, украшения
\end{abstract}

Гендерные исследования являются трендом последнего времени в гуманитарных науках, в том числе и археологии. Одним из зачинателей этого направления в археологии Казахстана является Ф.Х. Арсланова. Библиография научных трудов Ф.Х. Арслановой составляет 80 статей, в 2013 г. увидели свет ее публикации, не изданные в свое время по разным причинам. Значительная часть этих работ посвящена апробации материалов эпохи средневековья Верхнего и Среднего Прииртышья, необходимость в исследовании которой была обозначена Ф.Х. Арслановой на страницах кандидатской диссертации: «По своему географическому положению долина верхнего и среднего Иртыша являлась как бы связующим звеном между тюркскими племенами Алтая и Центрального Казахстана... Памятники материальной культуры этих племен изучены слабо, хотя исследование их имеет важное значение для разработки проблемы сложения казахского народа» [Арсланова, 1964]. Порядка десяти статей были посвящены обсуждению статуса женщины в кимакском обществе. Был проанализирован состав погребального инвентаря женских погребений, происходящих с Верхнего и Среднего Прииртышья (Зевакинский, Бобровский могильник, Карашат I, Белокаменка), в обобщающих исследованиях территория научного поиска расширилась и включила в себя Обь-Иртышское междуречье, Алтай, Кемеровский Кузбасс и Минусинскую котловину.

Фирая Хабибуловна Арсланова (1934-1995) является одним из ведущих исследователей древностей Восточного Казахстана (рис. 1). Она работала здесь с 1960-х годов по 1974 г. (с 1965 по 1974 гг. являлась преподавателем Усть-Каменогорского пе- 
дагогического института) [Жукова, Степанова, 2003, с. 389], а также в период с 1981 по 1987 гг. [Могильников, Плетнева, 2000, с. 219].

Богатейшая история региона обусловила широкий научный спектр исследователя: одинаково уверенно изучались и вводились в научный оборот памятники различных времен, от бронзового века до эпохи средневековья. Исключительную роль в формировании современных представлений об определенных страницах прошлого евразийских степей при этом играют результаты исследования Ф.Х. Арслановой памятников эпохи средневековья. В результате исследования таких могильников, как Зевакинский, Орловский, Бобровский, Камышинский, Трофимовский, Покровский, на страницах публикаций, посвященных введению в научный оборот этих материалов, предстала яркая и своеобразная культура кимаков - одного из тюркских племен, создавших на берегах Иртыша в IX-XI вв. свое государство. Львиная часть того, что нам известно о них, появилась в результате неустанной исследовательской работы Ф.Х. Арслановой.

Личность исследователя, несомненно, играет решающую роль в его научном творчестве. Вполне возможно, что лидерские качества, присущие самой Ф.Х. Арслановой, позволили впервые в археологии Казахстана поднять вопрос о статусе женщин в эпоху средневековья на основании анализа данных кимакских погребений. Хотелось бы отметить два факта из ее биографии, свидетельствующие о сильном, волевом характере исследователя. Она хотела стать геологом, но в поезде, когда ехала подавать документы в вуз, познакомилась с участниками знаменитой Хорезмской археологической

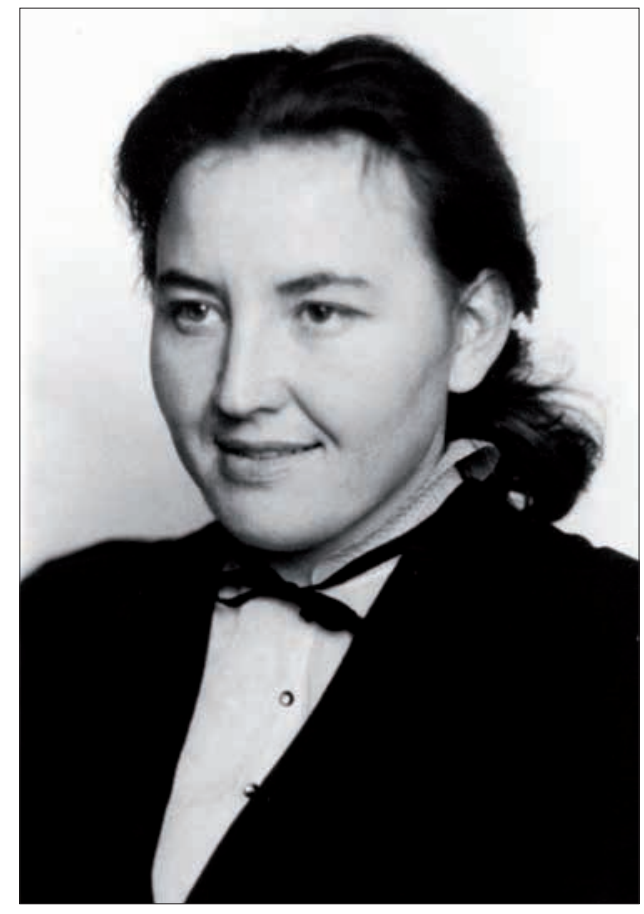

Рис. 1. Ф.Х. Арсланова. Фото из архива 3. Самашева

Fig. 1. F.Kh. Arslanova. Photo from Samashev Z. archive's

экспедиции и в результате приняла решение поступить на исторический факультет [Могильников, Плетнева, 2000]. Еще один важный момент в творческой жизни Ф.Х. Арслановой связан со сбором информации для защиты кандидатской диссертации. Ею более чем решительно были собраны материалы для диссертации «Археологические памятники Среднего Прииртышья», которая была успешно защищена в 1964 г., научный руководитель - А.Х. Маргулан [деятельности А.Х. Маргулана и других участников Центрально-Казахстанской экспедиции посвящена специальная статья: Бейсенов, Джумабекова, Базарбаева, 2017 - прим. авт.]. За два полевых сезона 1960-1961 гг. отряд Центрально-Казахстанской археологической экспедиции под руковод- 
ством Ф.Х. Арслановой провел исследование 86 курганов, именно по этим материалам была написана диссертация, в которой рассмотрены вопросы хронологии, осуществлен поиск аналогий в погребальном обряде и инвентаре, сделаны выводы о хозяйстве, религии населения Среднего Прииртышья, обоснована кимакская этническая принадлежность памятников эпохи развитого средневековья этого региона [Арсланова, 1964].

Ф.Х. Арсланова осталась в памяти тех, кто знал ее «удалой, неукротимой и мощной степной “поляницей”» [Могильников, Плетнева, 2000]. Один из учеников Ф.Х. Арслановой 3. Самашев пишет о впечатлении, которое она произвела на него при первой встрече и обращает внимание на гордо посаженную голову, решительные движения [Самашев, 2015 , с. 17]. Еще один исследователь, Г.Г. Петенева, работавшая с ней вместе, свидетельствует: «По своей природе она была лидер, командир и в быту и, конечно, на работе» [Петенева, 2017, с. 150]. Ее ученицы из Тверского государственного университета - Е.В. Лагуткина и Е.Г. Мойкина называют Фираю Хабибуловну инициатором многих новаций в археологическом изучении Тверской области и отмечают, что результаты ее деятельности оказывают влияние на изучение региона вплоть до настоящего времени [Лагуткина, Мойкина, 2011, с. 100-104].

И при всем этом она оставалась заботливой и внимательной женщиной. Ее запомнили на раскопках Маяцкого городища в 1979-1980 гг. именно такой: «Энергичная, всегда предельно занятая, всегда готовая помочь или чем-нибудь порадовать членов экспедиции» [Могильников, Плетнева, 2000]. Г.Г. Петенева также пишет в своих воспоминаниях, что, когда была необходима помощь, она «подмечала и помогала, добиваясь того, чтобы проблема была решена» [Петенева, 2017, с. 150]. Так и сложилось, что в научном творчестве этой незаурядной женщины значительное место занимают гендерные исследования.

В качестве источниковой базы для предпринятой работы в первую очередь послужили предметы торевтики, с помощью которых оформлялись костюм, конское снаряжение, вооружение, отдельные бытовые предметы. Эти вещи в силу своей высокой значимости являются ценнейшим источником для палеосоциологических исследований. Разнообразные женские и мужские украшения, поясная, конская гарнитура, зеркала, обнаруженные в кимакских погребениях, были выполнены из бронзы, серебра, золота.

Одной из причин того, что исследовательницей были сделаны важные выводы о положении женщины в эпоху средневековья, стало, несомненно, обнаружение богатых погребений кимакской знати. Так, в составе центрального женского погребения в ограде 1 длинного кургана 146 Зевакинского могильника, исследованного в 1969 г., находилось бронзовое амальгированное зеркало с рунической надписью. Ее чтение, выполненное тюркологом С.Г. Кляшторным, напрямую свидетельствовало о том, что предмет принадлежал знатной женщине. В первой строке надписи, согласно переводу, было написано: «Знатная женщина освобождается от своего [чувства] зависти (гнева). Ее счастливый удел (ее благость) наступает» [Арсланова, Кляшторный, 1973 , с. 313]. 
В 1981 г. Ф.Х. Арсланова публикует первую работу, посвященную анализу собственно предметов торевтики под названием «Культовые предметы из женских захоронений Прииртышья» [Арсланова, 1981, с. 48-49]. Источниковой базой послужили материалы трех женских погребений из Верхнего Прииртышья, двух - из Павлодарского Прииртышья, погребения у с. Мало-Панюшево (Приобское плато), в которых были найдены скульптурки рыб, птиц, личин, дракона. Автор акцентирует внимание на том факте, что данные погребения являлись центральными как в могильнике, так и в составе семейной группы. Данное обстоятельство, наряду с наличием специфических предметов украшений в оформлении костюма их владелиц, позволило прийти к выводу, что захороненные женщины при жизни могли отправлять определенные действия, связанные с религиозными церемониями. Обращает внимание, что фигуркам рыб сопутствуют украшения с образом птицы (подвески в виде крыльев, сердцевидные подвески, изображающие стилизованных птиц, булавка). По мнению автора, «данное сочетание позволяет предположить, что умершие женщины, похороненные вместе с такими предметами, являлись служительницами культа Умай» [Арсланова, 1981, с. 49].

В соавторстве с А.С. Ермолаевой были введены в научный оборот материалы кургана № 14 могильника у с. Измайловка и погребения у с. Белокаменка, работы проводились Шульбинской археологической экспедицией [Арсланова, Ермолаева, 1984, c. 141-145]. Особый интерес представляет находка бронзовой личины в погребении у с. Белокаменка. Высказано интересное предположение о назначении данного предмета: он является «вместилищем духа предка», a погребенная была, по-видимому, его хранительницей и, возможно, сама руководила определенными религиозными обрядами [Арсланова, Ермолаева, 1984, с. 143]. Об этом свидетельствуют состав инвентаря и наличие безинвентарного сопроводительного захоронения мужчины, занимавшего, по-видимому, зависимое положение.

В том же сборнике публикуются результаты изучения еще одного памятника, давшего интересные материалы, могильника Карашат, на этот раз совместно с 3. Самашевым. Отмечено, что как правило, «южнее основного захоронения (чаще всего мужчин) подхоранивали взрослых и детей мужского пола, а к северу от него - сородичей женского пола» [Арсланова, Самашев, 1984, с. 165]. В качестве объяснения таких особенностей планиграфии могильников, авторы приводят сведения о делении жилища на мужскую и женскую половины [Арсланова, Самашев, 1984, c. 165].

Спустя несколько лет Ф.Х. Арсланова и 3.С. Самашев возвращаются к материалам могильника Карашат I, в этой статье они дают более развернутую характеристику погребального обряда [Арсланова, Самашев, 1987, c. 122-133]. Подчеркивается, что женские могилы были центральными в общей усыпальнице и отличались от остальных погребений богатым набором инвентаря, что позволяет отнести их «к особой группе знатных женщин, возможно, возглавлявших определенные религиозные обряды» [Арсланова, Самашев, 1987, с. 127].

Крайне сжато, но емко в статье «К вопросу интерпретации украшений женской одежды из двух кур- 
ганных групп Кемеровской области» автором рассмотрено назначение ряда изделий из двух женских погребений у с. Ур-Бедари и у с. Тарасово на основании параллелей с археологическим материалом из ОбьИртышского междуречья [Арсланова, 1987a, с. 169-172]. Рассмотренные изделия из металла и камня являлись принадлежностью одежды ритуального назначения. На это указывают этнографические параллели. В качестве заключения автором постулируется следующий тезис: «Распространение в среде кимаков в период сложения государства (IX-X вв.) образов буддийско-тюркского пантеона, в частности, Тенгри и его супруги Умай отражает сложную социальную стратификацию этого общества и одновременно указывает на преемственную связь традиционных культов и религиозных обрядов с древнетюркскими» [Арсланова, 1987a, с. 172].

В статье «Длинные курганы Прииртышья» на основании более широкого археологического материала Ф.Х. Арсланова возвращается к закономерностям в планиграфии кимакских некрополей. Проанализированы данные по планиграфии 49 длинных курганов, в которых насчитывалось 163 могилы, включающие 170 погребения. Исследовательница отмечает, что Зевакинский могильник является наиболее полно исследованным из числа имеющихся на то время, в нем было раскопано 24 длинных кургана, содержавших 83 могилы с 89 умершими [Арсланова, 1987б, с. 51]. Выявлено, что в общих семейных усыпальницах правая сторона (северные ограды) по отношению к центральному мужскому захоронению предназначалась для женщин и девочек-подростков, а ле- вая - для мужчин и, соответственно, мальчиков-подростков» [Арсланова, 1987б, с. 61].

В период с 1989 по 1998 гг. издаются публикации, в которых подробно изучаются функции предметов торевтики в вещном мире кимаков. Так, в статье «Образ птицы на головных уборах кимакских женщин» проанализированы литые объемные скульптурки, а также уплощенные барельефные изображения хищных фантастических птиц, обнаруженные в ряде женских погребений в Прииртышье и на сопредельных территориях [Арсланова, 1989, с. 156-160]. Автор подчеркивает: «в стилистическом отношении эти произведения имеют много общих черт. В частности, гребень на поднятой голове птицы обозначен в виде треугольного выступа, сомкнутый клюв сильно загнут вниз, глаз передан овальным или округлым углублением. Оперение подчеркнуто полуовальными углублениями» [Арсланова, 1989, с. 156].

Образ птицы, по данным автоpa, играл важную роль как в предшествующий период, так и в этнографическое время. Приводятся сведения по этнографии тюркских народов, свидетельствующие о высокой знаковой сущности птичьей символики. «Анализ сопутствующих изделий прикладного искусства из этих же курганов, являвшихся также предметами, содержащими определенную религиозную символику, позволяет предположить о принадлежности погребенных с такими вещами людей к особой социальной группе кимакского общества, возглавлявшей, повидимому, определенные языческие обряды» [Арсланова, 1989, с. 160].

В статье «Женские погребения IX-X вв. с бусами из Казахстанского Прииртышья», вышедшей в 1998 г., 
проанализированы различные украшения, в том числе предметы торевтики, обнаруженные в женских и детских погребениях курганов Зевакинского могильника, у с. Выдриха, могильников Карашат I, у с. Белокаменка (рис. 2; 3) [Арсланова, 1998, c. 97-109]. Анализ инвентаря позволил автору прийти к выводу, что: «... бусы, исполнявшие сакральную функцию и являвшиеся дорогостоящими импортными изделиями, были использованы только представительницами социальной верхушки общества. На это указывает и преобладание в данных захоронениях других импортных изделий (китайские монеты, серебряные зеркала, подвески), а также специфических металлических украшений, связанных с языческими поверьями...» [Арсланова, 1998, c. 104]. Сделаны важные наблюдения по планиграфии кимакских могильников. Только два женских погребения были основными, все остальные находились в пристроенных оградах. Девочек и женщин до 50 лет, как правило, хоронили в южных (попреимуществу) или северных оградах по отношению к центральному мужскому погребению [Арсланова, 1998, с. 97].

Своеобразный итог по изучению кимакских древностей Ф.Х. Арслановой представляют две обширные статьи по воинским захоронениям в Зевакинском могильнике и женским украшениям кимаков и кыпчаков, вышедшие, к сожалению, только после смерти исследовательницы [Арсланова, 2013а, с. 28-92; 20136, с. 93-120]. В статье по женским украшениям детально представлена одна из интересных категорий украшений - застежки в виде летящей птицы, нередко, с изображением личины на туловище. На момент изучения насчитывалось 43 экз. подобных изделий (из них 24 экз. образуют комплекты, а 19 - половинки) [Арсланова, 2013, с. 93]. Они происходят из 22 женских и четырех детских погребений, находящихся в составе 21 курганной группы с территории Обь-Иртышского междуречья, Алтая, Кемеровского Кузбасса и Минусинской котловины [Арсланова, 2013, с. 108, рис. 7]. Комплексное изучение погребального обряда и погребального инвентаря, обращение к данным этнографии позволили исследовательнице прийти к важным выводам по функции, способу ношения, семантике этих украшений. Несмотря на то, что Ф.Х. Арсланова не ставила своей задачей акцентировать внимание на социальном статусе женщин, неоднократно отмечается, что наличие обрядовой одежды, неординарность погребального инвентаря указывает на их принадлежность к элитарной части общества и, что, возможно, при жизни они были служительницами культа [Арсланова, 2013, с. 97].

Послепереезда в 1974 г. вг. Тверь работы по изучению кимакских древностей продолжались и, конечно, исследовательница сосредоточилась на изучении славянской археологии. Как совершенно верно отметили В.А. Могильников и С.А. Плетнева в статье, посвященной памяти Ф.Х. Арслановой, в ее научном творчестве «соединились две средневековые, но абсолютно разные культуры: кочевническая и славянская-земледельческая. Этот редчайший пример симбиоза мог быть исключительно у ученого необычайного трудолюбия и исследовательского таланта» [Могильников, Плетнева, 2000]. И здесь удача сопутствовала ученому. В Избрижском могильнике, расположенном в Тверской области РФ, Ф.Х. Арслановой 


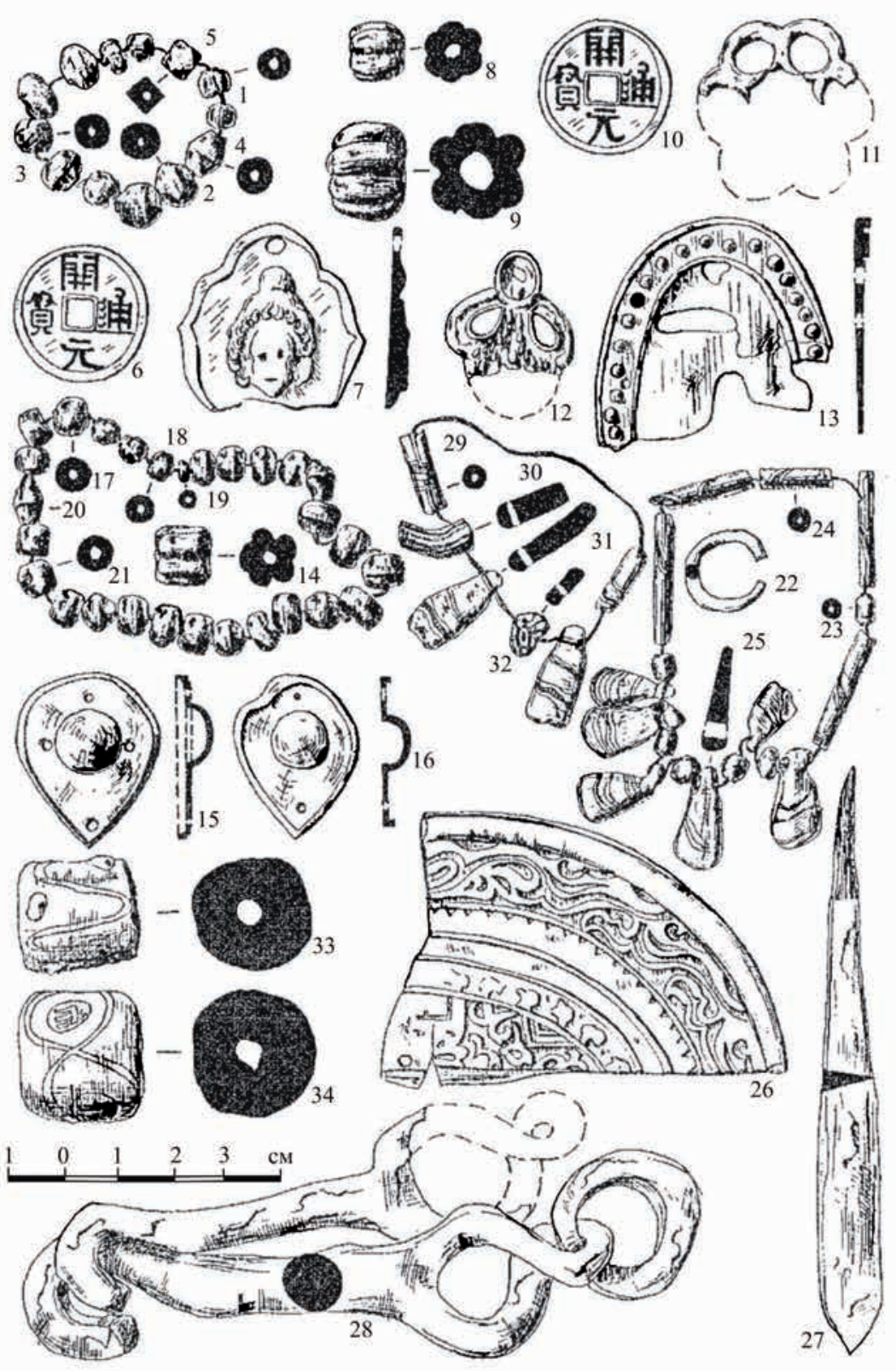

Рис. 2. Иллюстраџия к статье «Женские погребения с бусами $I X-X$ вв. из Казахстанского Прииртылшья» (по: [Арсланова, 1998, рис. 1])

Fig. 2. Illustration from the article "Zhenskie pogrebeniya s busami $I X-X v v$. iz Kazahstanskogo Priirtysh'ya” (by: [Arslanova, 1998, fig. 1])

также были найдены женские погребения с богатым составом украшений [Жукова, Степанова, 2002, с. 6]. Одна из статей, содержащая результаты изучения этого региона, имеет более чем говорящее название: «Языческие символы в одежде женщины первой половины XI в. (по материалам кур- 


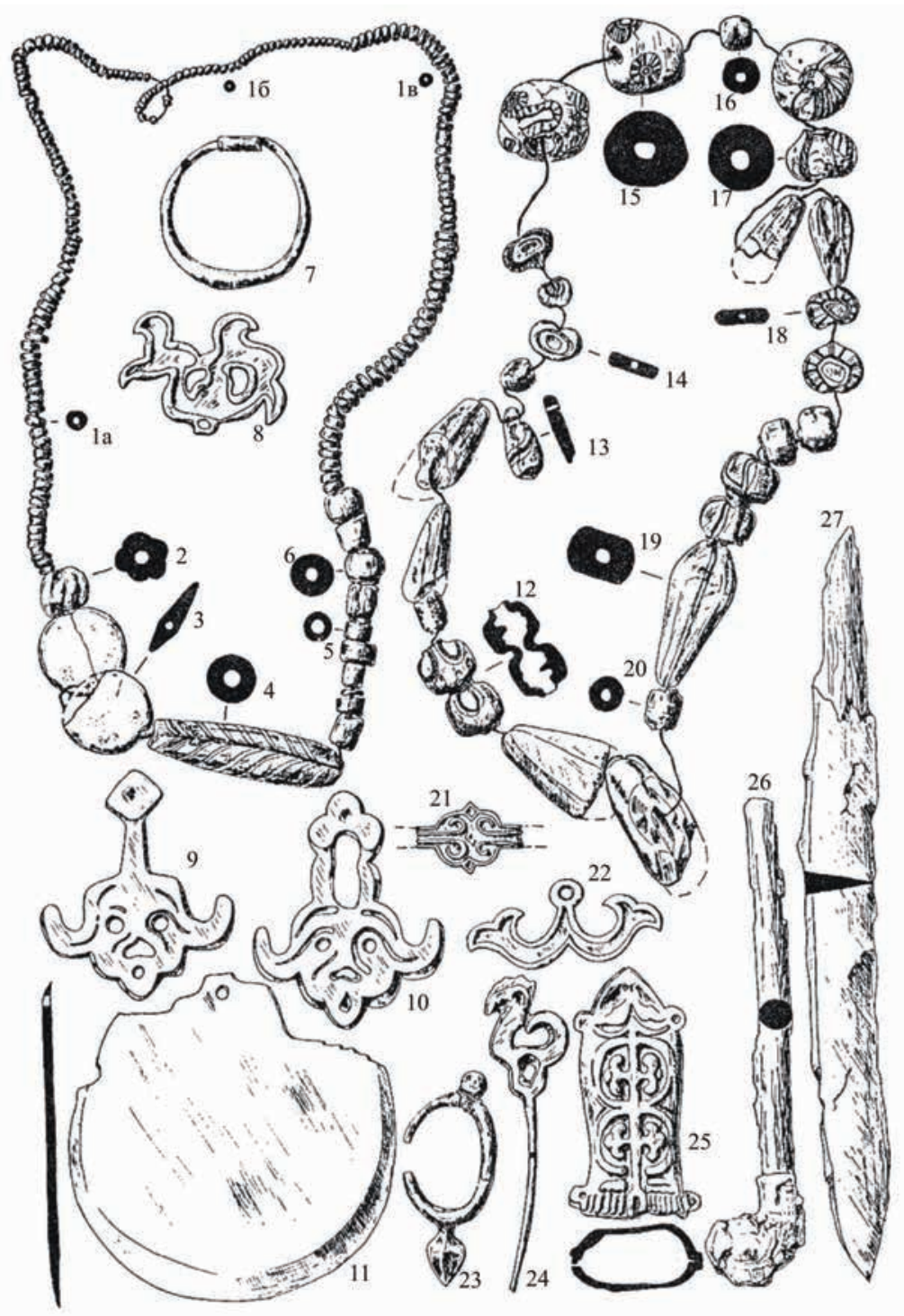

Рис. 3. Иллюстрачия к статье «Женские погребения с бусами $I X-X$ вв. из Казахстанского Прииртышья» (по: [Арсланова, 1998, рис. 2])

Fig. 3. Illustration from the article "Zhenskie pogrebeniya s busami $I X-X v v$. iz Kazahstanskogo Priirtysh 'ya” (by: [Arslanova, 1998, fig. 2])

ганов у с. Избрижье)» [Могильников, Плетнева, 2000].

Таким образом, размышления на гендерную тематику стали возможны в результате изучения знаковой сущности отдельных предметов и планиграфии могильников. Автором высказано мнение об особом соци- альном статусе женщин, чей погребальный инвентарь содержал предметы торевтики (эти погребения также отличались специфическим размещением в составе семейной группы и в пространстве могильника). Несмотря на то, что исследовательницей были получены важнейшие сведения по по- 
Хасенова Б.М. Статус женщины в кимакском обществе в трудах Ф.Х. Арслановой

гребальному обряду представителей кимакской знати, важно отметить, что в научном плане ее интересовал статус именно женщины. Эту тему она разрабатывала на протяжении многих лет. Можно сказать, что Ф.Х. Арсланова стала новатором гендерных ис- следований в археологии Казахстана. Причем, необходимо отметить, что в классическом понимании термина, ведь под гендерными исследованиями изначально подразумевалось изучение женщин и лишь спустя время к ним добавились и мужчины.

Работа выполнена при финансовой поддержке Комитета науки Министерства образования и науки Республики Казахстан (ИРН проекта АР05131573).

\section{ЛИТЕРАТУРА}

1. Арсланова Ф.Х. Археологические памятники Среднего Прииртышья: автореф. дис. ... канд. ист. наук. Алма-Ата, 1964.

2. Арсланова Ф.Х. Культовые предметы из женских захоронений Прииртышья // Методологические аспекты археологических и этнографических исследований в Западной Сибири. Томск, 1981. С. 48-49.

3. Арсланова Ф.X. К вопросу интерпретации украшений женской одежды из двух курганных групп Кемеровской области // Проблемы археологии степной Евразии: тез. докл. Кемерово, 1987а. Ч. 2. С. 169-172.

4. Арсланова Ф.Х. Длинные курганы Прииртышья // Источники по истории Западной Сибири. История и археология. Омск, 1987б. С. 50-69.

5. Арсланова Ф.Х. Образ птицы на головных уборах кимакских женщин // Маргулановские чтения: сб. матер. конф. Алма-Ата, 1989. С. 156-160.

6. Арсланова Ф.Х. Женские погребения IX-X вв. с бусами из Казахстанского Прииртышья // Вопросы археологии Казахстана. Алматы-Москва, 1998. Вып. 2. C. $97-109$.

7. Арсланова Ф.Х. Воинские захоронения кимаков в Зевакинском могильнике / Арсланова Ф. Очерки средневековой археологии Верхнего Прииртышья. Астана издат. группа филиала Института археологии им. А.Х. Маргулана в г. Астана, 2013a. C. 28-92.

8. Арсланова Ф.Х. Женские украшения кимаков и кыпчаков / Арсланова Ф. Очерки средневековой археологии Верхнего Прииртышья. Астана: издат. группа филиала Института археологии им. А.Х. Маргулана в г. Астана, 2013б. С. 93-120.

9. Арсланова Ф.Х., Ермолаева А.С. Памятники кимаков левобережья Иртыша // Этническая история тюркоязычных народов Сибири и сопредельных территорий: тез. докл. обл. научн. конф. по антропологии, археологии и этнографии. Омск, 1984. C. 141-145.

10. Арсланова Ф.Х., Кляшторный С.Г. Руническая надпись на зеркале из Верхнего Прииртышья // Тюркологический сборник-1972. М., 1973. С. 306-315.

11. Арсланова Ф.Х., Самашев 3.С. Курганная группа «Карашат» в Семипалатинской области // Этническая история тюркоязычных народов Сибири и сопредельных территорий: тез. докл. обл. научн. конф. по антропологии, археологии и этнографии. Омск, 1984. С. 161-165.

12. Арсланова Ф.Х., Самашев 3.С. Курганы кимаков в Семипалатинском Прииртышье // Проблемы средневековой археологии Урала и Поволжья. Уфа, 1987. C. $122-133$. 
13. Бейсенов А.З., Джумабекова Г.С., Базарбаева Г.А. Путь к изучению древностей центра страны: история создания первой археологической экспедиции Казахской Академии наук // Археологическое наследие Центрального Казахстана: изучение и сохрание. Алматы: НИЦИА «Бегазы-Тасмола», 2017. Т. 1. С. 11-64.

14. Жукова Е.Н., Степанова Е.В. К юбилею Ф.Х. Арслановой // Тверь, Тверская земля и сопредельные территории. Тверь, 2002. Вып. 5. С. 389-400.

15. Лагуткина Е.В., Мойкина Е.Г. Наследие Ф.Х. Арслановой и А.А. Чарикова в Тверском государственном музее // Археология Казахстана в эпоху независимости: итоги, перспективы: матер. междунар. научн. конф., посвящ. 20-летию независимости Республики Казахстан и 20-летию Института археологии им. А.Х. Маргулана КН МОН РК. Алматы: Институт археологии им. А.Х. Маргулана, 2011. С. 100-109.

16. Могильников В.А., Плетнева С.А. Памяти Ф.Х. Арслановой // Татарская археология. 2000. № 1-2 (6-7). С. 214-224.

17. Петенева Г.Г. Остался мой след далеко за порогами. С моими трудами, с моими тревогами // Археологическое наследие Центрального Казахстана: изучение и сохранение. Алматы: НИЦИА «Бегазы-Тасмола», 2017. Т. 1. С. 149-152.

18. Самашев 3. Предисловие / Арсланова Ф. Очерки средневековой археологии Верхнего Прииртышья. Астана: издат. группа филиала Института археологии им. А.Х. Маргулана в г. Астана, 2013. 405 с.

\section{Сведения об авторе:}

Хасенова Бахыт Мулдашевна - докторант очной формы обучения, Евразийский национальный университет им. Л.Н. Гумилева, научный сотрудник, Институт археологии им. А.Х. Маргулана (г. Нур-Султан, Казахстан); alicar@inbox.ru

\section{Ф.Х. АРСЛАНОВАНЫҢ ЕНБЕКТЕРІНДЕГІ ҚИМАҚ ҚОҒАМЫНДАҒЫ ӘЙЕЛ МӘРТЕБЕСІ}

\section{Б.М. Хасенова}

Ф.Х. Арсланованың ғылыми шығармашылығында гендерлік зерттеулер айтарлықтай орын алады. Автор, жерлеу мүкәммалдарында торевтика бұйымдары (сондай-ақ, бұл жерлеулер отбасылық топ және қорымның кеңістігінде өзіндік орналасумен ерекшеленеді) кездесетін жерлеулердегі әйелдердің әлеуметтік мәртебелерінің ерекше болғандығы туралы пікір айтады. Зерттеуші тарапынан қимақ ақсүйектерін жерлеу рәсімдері туралы маңызды мәліметтер алынғанына қарамастан, ғылыми тұрғыдан алғанда әйелдердің мәртебесі ғалымның басты қызығушылығын туғызған. Ф.Х. Арсланова Қазақстан археологиясында гендерлік зерттеулердің көшбасы болды.

Түйін сөздер: археология, Ф.Х. Арсланова, Шығыс Қазахстан, Ертіс жағалау, ортағасыр дәуірі, Қимақ кағанаты, археологиясы тарихы, қоғам, гендерлік зерттеулер, әйел, әшекейлер

\section{THE STATUS OF A WOMAN IN KIMAK SOCIETY IN WORKS OF F.Kh. ARSLANOVA}

\section{B.M. Khassenova}

In the scientific work of F.Kh. Arslanova significant place occupied by gender studies. The author expressed an opinion about the special social status of women, whose funeral inventory contained toreutics objects (these burials also differed by specific placement in the family group and in the burial space). Despite the fact that the researcher obtained the most important information on the funeral rite of representatives of the Kimak nobility, it is important to note that in scientific terms she was interested in the status of the woman. F.Kh. Arslanova became an innovator of gender studies in the archaeology of Kazakhstan. 
Хасенова Б.M. Статус женщины в кимакском обществе в трудах Ф.Х. Арслановой

Keywords: archaeology, F.Kh. Arslanova, Eastern Kazakhstan, Upper Irtysh, Middle Ages, Kimak Kaganate, history of archaeology, society, gender studies, woman, jewelry

\section{REFERENCES}

1. Arslanova, F. Kh. 1964. Arkheologicheskie pamyatniki Srednego Priirtysh'ya: avtoref. dis. ... kand. ist. nauk (Archaeological sites of the Middle Irtysh: thes. dis. ... Cand. hist. sciences). Alma-Ata (in Russian).

2. Arslanova, F. Kh. 1981. In Metodologicheskie aspekty arkheologicheskikh $i$ ehtnograficheskikh issledovanij $v$ Zapadnoi Sibiri (Methodological aspects of archaeological and ethnographic studies in Western Siberia). Tomsk 48-49 (in Russian).

3. Arslanova, F. Kh. 1987a. In Problemy arkheologii stepnoi Evrazii (Problems of the archeology of the steppe Eurasia), 2. Kemerovo 169-172 (in Russian).

4. Arslanova, F. Kh. 1987b. In Istochniki po istorii Zapadnoj Sibiri. Istoriya i arkheologiya (Sources on the history of Western Siberia). Omsk 50-69 (in Russian).

5. Arslanova, F. Kh. 1989. In Margulanovskie chteniya (Margulan reading-1989). Alma-Ata 156-160 (in Russian).

6. Arslanova, F. Kh. 1998. In Voprosy arheologii Kazahstana (Questions of archaeology of Kazakhstan), 2. Almaty-Moscow 97-109 (in Russian).

7. Arslanova, F. Kh. 2013a. In Arslanova F. Ocherki srednevekovoi arheologii Verhnego Priirtysh'ya (Sketches of medieval archeology of the Upper Irtysh). Astana 28-92 (in Russian).

8. Arslanova, F. Kh. 2013b. In Arslanova F. Ocherki srednevekovoi arheologii Verhnego Priirtysh'ya (Sketches of medieval archeology of the Upper Irtysh). Astana 93-120 (in Russian).

9. Arslanova, F. Kh., Ermolaeva, A. S. 1984. In Etnicheskaya istoriya tyurkoyazychnykh narodov Sibiri i sopredel'nykh territorii (Ethnic history of the Turkic-speaking peoples of Siberia and adjacent territories). Omsk 141-145 (in Russian).

10. Arslanova, F. Kh., Klyashtornyi, S. G. 1973. In Tyurkologicheskij sbornik-1972 (Türkological collection-1972). Moscow 306-315 (in Russian).

11. Arslanova, F. Kh., Samashev, Z. S. 1984. In Etnicheskaya istoriya tyurkoyazychnykh narodov Sibiri i sopredel'nykh territorii (Ethnic history of the Turkic-speaking peoples of Siberia and adjacent territories). Omsk 161-165 (in Russian).

12. Arslanova, F. Kh., Samashev, Z. S. 1987. In Problemy srednevekovoj arkheologii Urala i Povolzh'ya (Problems of medieval archaeology of the Urals and Volga region). Ufa 122-133 (in Russian).

13. Beisenov, A. Z., Jumabekova, G. S., Bazarbayeva, G. A. 2017. In Beisenov, A. Z. (ed.) Arkheologicheskoe nasledie Tsentral'nogo Kazakhstana: izuchenie b sohranenie (Archaeological heritage of Central Kazakhstan: the study and preservation), 1. Almaty: "Begazy-Tasmola" Publ., 11-64 (in Russian).

14. Zhukova, E. N., Stepanova, E. V. 2002. In Tver', Tverskaya zemlya i sopredel'nye territorii (Tver, Tver land and adjacent territories), 5. Tver 389-400 (in Russian).

15. Lagutkina, E. V., Moikina, E. G. 2011. In Baitanayev, B. A., Beisenov, A. Z., (eds.) Arheologiya Kazahstana v ehpohu nezavisimosti: itogi, perspektivy (Archeology of Kazakhstan in the era of independence: results, prospects). Almaty: A.Kh. Margulan Institute of Archaeology, 100-109 (in Russian).

16. Mogil'nikov, V. A., Pletneva, S. A. 2000. In Tatarskaya arkheologiya (Tatar archaeology), 1-2 (6-7), 214-224 (in Russian). 
17. Peteneva, G. G. 2017. In Beisenov, A. Z. (ed.) Arkheologicheskoe nasledie Tsentral'nogo Kazakhstana: izuchenie b sohranenie (Archaeological heritage of Central Kazakhstan: the study and preservation), 1. Almaty: "Begazy-Tasmola" Publ., 149-152 (in Russian).

18. Samashev, Z. 2013. In Arslanova F. Ocherki srednevekovoj arkheologii Verkhnego Priirtysh'ya (Sketches of medieval archaeology of the Upper Irtysh). Astana, 17 (in Russian).

\section{About the Author}

Khassenova Bakyt M. Full-time doctoral student, Eurasian National University after L.N. Gumilyov; Researcher, A.Kh. Margulan Archeology Institute, Nur-Sultan, Kazakhstan; alicar@inbox.ru

\footnotetext{
Мүдделер қақтығысы туралы ақпаратты ашу. Автор мүдделер қақтығысының жоқтығын мәлімдейді. / Раскрытие информации о конфликте интересов. Автор заявляет об отсутствии конфликта интересов.

/ Disclosure of conflict of interest information. The author claims no conflict of interest.

Мақала туралы ақпарат / Информация о статье / Information about the article.

Редакцияға түсті / Поступила в редакцию / Entered the editorial office: 22.09.2018.

Рецензенттер мақұлдаған / Одобрено рецензентами / Approved by reviewers: 01.10.2018.

Жариялауға қабылданды / Принята к публикации / Accepted for publication: 08.10.2018.
} 